\title{
PETIK LAUT DALAM TINJAUAN SAINS DAN ISLAM
}

\author{
Asri Sawiji ${ }^{1}$, Mauludiyah ${ }^{1}$ dan Misbakhul Munir ${ }^{2}$ \\ ${ }^{1}$ Program Studi Ilmu Kelautan, Universitas Islam Negeri Sunan Ampel, Jl. Jend. A. Yani 117 Surabaya \\ Email: sawiji.asri@uinsby.ac.id \\ Email:mauludiyah@uinsby.ac.id \\ ${ }^{2}$ Program Studi Biologi, Universitas Islam Negeri Sunan Ampel, Jl. Jend. A. Yani 117 Surabaya \\ Email: misbakhul_munir@uinsby.ac.id
}

\begin{abstract}
ABSTRAK
Tradisi petik laut sering juga disebut dengan larung sesaji yang dikaitkan dengan syukuran para nelayan atas segala hal yang telah diberikan oleh laut. Saat ini petik laut telah mengalami transformasi menjadi ajang pesta rakyat, namun sejatinya ritual petik laut ini merupakan ekspresi spiritualitas komunitas nelayan pesisir di Jawa dan Madura. Untuk menjaga salah satu kearifan lokal tersebut maka perlu dilakukan kajian yang komprehensif mengenai tradisi petik laut dalam tinjauan sains dan Islam. Secara spesifik, penelitian ini bertujuan untuk mengetahui pengaruh bacaan $\mathrm{Al}$ Quran pada pertumbuhan mikroorganisme atau bakteri air laut. Hal ini dikarenakan mikroorganisme atau bakteri merupakan salah satu aktor yang berperan penting dalam sistem kelautan yang selanjutnya akan mempengaruhi produktivitas perairan dan hasil tangkap. Pengambilan sampel air laut yang digunakan dalam penelitian ini adalah air laut di pesisir Sidoarjo. Sampel diambil pada permukaan air laut sejauh 100 meter dari bibir pantai dan dilakukan sekali untuk semua sampel. Analisa pertumbuhan mikroorganisme air laut dilakukan di laboratorium mikrobiologi. Perlakuan yang diberikan adalah dibacakan (1) surat an-Nahl, (2) al-Fatihah, dan (3) tanpa perlakuan (kontrol). Sampel pengontrol (pre-test/baseline) dan sesudah perlakuan (post test) ditumbuhkan dalam media NA dengan teknik Total Plate Count (TPC) di laboratorium. Penghitungan jumlah bakteri dengan menggunakan colony counter dilakukan setelah diinkubasi selama 24 jam. Data hasil pengamatan jumlah koloni bakteri akan diuji dengan dengan menggunakan dua variabel yaitu perlakuan dan hari. Hasil analisa statistik dengan menggunakan analisis non-parametrik uji Friedman menunjukkan bahwa besaran nilai Chi Square $=30.545$ dan asymp sig sebesar 0.000. Hasil tersebut menunjukkan bahwa ketiga perlakuan (dibacakan surat an-Nahl, al-Fatihah dan tanpa perlakuan (kontrol)) memberikan reaksi yang berbeda dengan jumlah nilai TPC atau pertambahan koloni bakteri air laut.
\end{abstract}

Kata kunci: Petik Laut, living qur'an, mikroorganisme

\section{PENDAHULUAN}

Salah satu inkulturasi Islam dalam peri-kehidupan masyarakat nelayan adalah Selamatan Laut atau sering disebut juga dengan Petik Laut, atau Rokat Tase' bagi masyarakat Madura, atau Larung Sesaji bagi masyarakat Jawa. Petik laut adalah sebuah upacara tradisional atau ritual yang dilakukan masyarakat nelayan sebagai rasa syukur kepada Tuhan serta untuk memohon berkah rezeki dan keselamatan para nelayan. Tradisi ini telah dilakukan cukup lama terutama di pesisir pulau Jawa dan Madura, seperti misalnya di pesisir Sumenep, Pasuruan, Puger, Situbondo, dan Banyuwangi. Namun demikian, tradisi ini juga masih ditemukan di beberapa daerah di Sulawesi, Bali, dan Lombok (Dewi et.al., 2014). Inkulturasi Islam (dalam pengertian tekstualnormatif) terlihat dari adanya pembacaan Al-Quran (khataman), tahlil dan pembacaan doa secara Islami yang dipimpin oleh kiai setempat di samping tradisi lokal berupa aneka sesaji dan persembahan (Rohim, 2009). Tradisi petik laut ini dilaksanakan setiap bulan Muharam, atau bulan Suro dalam penanggalan Jawa, dengan cara membuang sesaji atau sajen ke tengah laut yang dilakukan oleh sesepuh atau pemuka agama dengan menggunakan perahu.

Tradisi petik laut yang dilakukan dengan cara dialog kebudayaan ini merupakan salah satu proses akulturasi Islam dengan tradisi lokal masyarakat nelayan di wilayah pesisir. Kebudayaan lokal yang bersumber dari keyakinan lokal tidak serta-merta dapat diubah begitu saja. Untuk itu, kaidah-kaidah pendekatan ilmiah, yang bercirikan penonjolan dimensi pengamatan, penalaran, penemuan, pengabsahan dan penjelasan tentang suatu kebenaran, diperlukan untuk melihat tradisi petik laut dalam kerangka agama-sains. Al-Quran mendorong kita untuk mencari ilmu pengetahuan dan memerintahkan kita untuk merenungkan alam semesta dalam bahasa yang dimengerti pada zamannya. Melalui QS. An-Nahl: 78, umat manusia diarahkan agar membiasakan diri untuk 
mengamati, karena salah satu fitrah yang dibawa sejak lahir adalah cenderung menggunakan mata terlebih dahulu, baru menggunakan hati (qalbu).

Untuk itu perlu dilakukan kajian yang komprehensif mengenai tradisi petik laut dalam tinjauan sains dan Islam sebagai bentuk menjaga salah satu kearifan lokal negeri ini. Secara spesifik, penelitian ini bertujuan untuk mengetahui pengaruh bacaan Al-Quran pada pertumbuhan mikroorganisme air laut. Parameter mikroorganisme dipilih karena merupakan salah satu aktor yang berperan penting dalam sistem kelautan (sebagai salah satu sumber makanan utama dan dekomposer) yang selanjutnya akan mempengaruhi produktivitas perairan dan hasil tangkap. Hasil penelitian ini diharapkan dapat berkontribusi dalam perkembangan keilmuan mikrobiologi dan ilmu air (water science).

\section{LIVING QUR'AN}

Slametan menurut penanggalan Jawa berhubungan dengan tahap-tahap kehidupan seorang manusia atau indvidu dan mengadopsi pola waktu Islam dalam menghitung rembulan. Orang Jawa merasa berkewajiban untuk merayakan periode-periode waktu suci dengan slametan. Satu Sura merupakan hari raya Buddha daripada hari raya Islam. Oleh karena itu Satu Sura hanya dirayakan oleh mereka yang secara sadar anti-Islam. Dengan tumbuhnya beberapa sekte anti-Islam yang bersemangat sejak masa perang serta munculnya guru-guru keagamaan yang mengkhotbahkan perlunya kembali kepada adat Jawa yang "asli". Frekuensi slametan Satu Sura mungkin telah sedikit meningkat. Beberapa individu tertentu yang anti-Islam bahkan berpuasa pada bulan Sura dan tidak dalam bulan Pasa, tetapi ini agak jarang terjadi (Geertz, 2014). Dalam slametan juga menggunakan al-Qur'an sebagai doa yang dihaturkan oleh masyarakat kepada Tuhan yang Maha Esa sebagai rasa terima kasih mereka. Terdapat ayat-ayat tertentu yang biasanya digunakan oleh masyarakat sebagai doa yang difungsikan sebagai obat.

Dari segi bahasa, Living Qur'an adalah gabungan dari dua kata, yaitu living yang berarti hidup dan Qur'an yang berarti (teks) Al-Quran yang hidup di masyarakat. Living Qur'an pada hakikatnya bermula dari fenomena yang dialami pada masyarakat umum dimana Al-Qur'an difungsikan dalam kehidupan praksis di luar kondisi tekstualnya. Hal ini muncul karena dalam praktek di masyarakat, pemaknaan kitab suci umat islam ini tidak hanya mengacu pada pemahaman atas pesan tekstual, tetapi juga fadhilah dari unit-unit tertentu teks Al-Quran bagi kepentingan praksis keseharian umat. Al-Quran dapat berfungsi sebagai pedoman hidup umat muslim, tonggak transformasi sosial, pembebasan masyarakat yang tertindas dan pencerah masyarakat dari kegelapan. Dalam ranah privat, Al-Qur'an biasa digunakan sebagai shifa' (obat penawar, pemberi solusi) untuk pribadi yang sedang dalam kesedihan atau musibah. Ayat-ayat al-Qur'an sekaligus berfungsi sebagai terapi psikis dan penawar untuk persoalan sosial individu. Selain itu, ayat-ayat tertentu juga diyakini dapat menjadi obat untuk mengobati penyakit fisik.

Sejarah mencatat bahwa praktik memperlakukan Al-Qur'an, baik surat atau ayat tertentu, untuk kehidupan praksis umat, sudah terjadi sejak masa awal islam, yakni pada zaman Rasulullah. Hal ini didasarkan atas sebuah hadits shahih yang diriwayatkan oleh Imam al-Bukhari dalam Shahih al-Bukhari. Dari 'Aisyah r.a berkata bahwa Nabi Muhammad pernah membaca surat al-Mu'awwidhatain yaitu surat al-Falaq dan an-Naas ketika beliau sedang sakit sebelum wafatnya (HR. Bukhari, Bab al-Raqa bi al-Quran). Rasulullah tidak hanya membaca kedua surat ini ketika menghadapi penyakit fisik, tetapi juga digunakan untuk perlindungan terhadap bahaya alam. Selain itu juga diriwayatkan 'Uqbah ibn 'Amir berkata, "Ketika saya berjalan bersama-sama dengan Rasulullah SAW di antara Juhfah dan Abwa, tiba-tiba kami diserang oleh angin kencang dan gelap yang amat sangat. Maka Rasulullah berlindung kepada Tuhan dengan membaca a'ūdzu birabbi 'l-falaq dan a'ūdzu birabbi 'n-nās, dan beliau bersabda kepadaku: "Wahai 'Uqbah berlindung pula lah engkau kepada Tuhan dengan membaca kedua surat itu, karena tidak ada suatu pun perlindungan yang lebih baik dari kedua-duanya". Berkata pula 'Uqbah: "Dan aku sering mendengar Nabi mengimami kami dalam shalat dengan membaca kedua surat itu" (HR. Abu Dawud). Hadits ini menyatakan bahwa menurut Nabi Muhammad SAW surat al-Falaq dan anNaas yang terdapat di bagian akhir Al-Qur'an jika dibaca dapat membuat pembacanya memperoleh perlindungan dari bahaya-bahaya yang begitu nyata, yang dialami ketika seseorang masih hidup (Putra, 2012).

Dalam riwayat lain disebutkan bahwa sahabat pernah mengobati seseorang yang tersengat hewan berbisa dengan membaca al-Fathihah (HR Bukhari, Bab al-Raqa bi Fatihat). Secara makna, surat Al-Fathihah sama sekali tidak ada kaitannya dengan sengatan binatang berbisa. Dari riwayat ini, beberapa praktek interaksi umat islam dapat dipahami dan berkembang pemahaman mengenai fadhilah atau khasiat serta keutamaan surat tertentu di dalam Al-Quran. Seperti yang telah difirmankan oleh Allah pada surat Ar-Ra'du: 31 yang artinya: 
"Dan sekiranya ada suatu bacaan (kitab suci) yang dengan bacaan itu gunung-gunung dapat digoncangkan atau bumi jadi terbelah atau oleh karenanya orang yang sudah mati dapat berbicara, (tentu Al-Quran itulah dia). Sebenarnya segala urusan itu adalah kepunyaan Allah”.

Selain itu, dalam studi healing qur'anic, dikatakan bahwa pengaruh luar biasa dari mendengarkan murattal AlQuran diantaranya adalah dapat meningkatkan kekebalan tubuh, mencegah penyakit ganas, menghilangkan rasa khawatir, ragu-ragu atau cemas, dan perubahan signifikan dalam perilaku.

\section{MIKROORGANISME LAUT}

Mikroorganisme ialah jasad renik yang mempunyai kemampuan sangat baik untuk bertahan hidup. Jasad renik tersebut dapat hidup hampir di semua tempat di permukaan bumi. Mikroorganisme mampu beradaptasi dengan lingkungan yang sangat dingin hingga lingkungan yang relatif panas, dari lingkungan yang asam hingga lingkungan yang relatif panas, serta dari lingkungan yang asam hingga basa. Mikroorganisme ini tidak dapat dilihat secara kasat mata. Oleh karena itu, untuk melihat miroorganisme diperlukan alat bantu berupa mikroskop (Afriyanto 2005).

Di perairan laut, peranan bakteri gram negatif heterotrof terdiri dari 90\% bakteri gram negatif (Bouman, 1981) yang mempunyai morfologi dan komposisi kimia sama dengan sel bakteri lainnya. Sama dengan jaringan metabolisme ditulis pada spesies tertentu tidak ada keistimewaan (Bertrand et al, 1976). Kelimpahan bakteri heterotrof, dalam ukuran biomassa, sesungguhnya dapat disejajarkan dengan biomassa fitoplankton laut. Temuan ini mendukung hipotesis Pomeroy (1974) tentang pentingnya peran bakteri heterotrof dalam laut dalam jejaring makanan laut. Di laut juga terdapat bakteri yang memiliki aktifitas mekanisme bioluminesens dalam semua kelompok organisme tersebut umumnya sama dan sangat menarik. Tampaknya bahwa aktivitas bioluminesens telah ada di sepanjang evolusi hidup mereka. Bakteri yang memiliki aktivitas bioluminesens kebanyakan adalah spesies-spesies dalam lingkungan laut (marine environments). Pemancaran cahaya yang dilakukan sangat menguntungkan organisme tersebut karena berguna untuk mencari makan, menghindari musuh, dan mengenal spesiesnya atau untuk mencari mangsa, komunikasi, dan aktivitas kamuflase.

Bakteri berfungsi untuk menguraikan komponen-komponen yang komplek menjadi komponen yang sederhana, yang mana awalnya komponen ini tidak dapat digunakan oleh organisme di lingkungan, dengan adanya bakteri, maka komponen tersebut dapat dimanfaatkan. Selain itu bakteri berperan pada produksi primer, sebagaimana diketahui bakteri ada yang autotrof maupun heterotrof. Bakteri autotrof yaitu bakteri yang menggunakan $\mathrm{CO}_{2}$ dan $\mathrm{H}_{2} \mathrm{O}$ untuk membentuk materi organik dengan bantuan energi yang berasal dari matahari (photoautotrof) ataupun energi yang berasal dari reaksikimia (Chemoautotrof). Bakteri juga dapat melakukan penanganan air limbah karena bakteri dapat digunakan untuk menguraikan senyawa-senyawa organik dalam air limbah menjadi senyawa sederhana. Selain itu bakteri juga dapat digunakan dalam penanganan polusi minyak bumi. Bakteri dapat menggunakan komponen minyak sebagai sumber karbon. Jadi komponen minyak yang berbahaya bagi lingkungan dapat digunakan oleh bakteri sebagai bahan makanan dan akhirnya dapat menghasilkan $\mathrm{CO}_{2}$ yang bisa di manfaatkan oleh bakteri organisme autotrof. Terdapat berbagai faktor yang berpengaruh terhadap pertumbuhan koloni bakteri, baik berupa penambahan maupun pengurangan, yaitu temperatur, keasaman $(\mathrm{pH})$, salinitas, dan oksigen.

\section{METODOLOGI PENELITIAN}

Penelitian ini mengkaji ritual petik laut berbasis Al-Quran dan sains dengan metodologi yang komprehensif, yaitu studi empiris yang dilaksanakan pada tahun pertama ini dan akan dilanjutkan dengan studi kasus pada penelitian tahun kedua. Studi empiris dilakukan untuk melihat fenomena yang benar-benar terjadi mengenai bagaimana pengaruh bacaan Al-Quran yang dilakukan dalam tradisi petik laut pada pertumbuhan mikroorganisme air laut.

Pengambilan sampel air laut yang digunakan dalam penelitian ini adalah air laut di pesisir Sidoarjo. Sampel diambil pada permukaan air laut sejauh 100 meter dari bibir pantai dan dilakukan sekali untuk semua sampel. Analisa pertumbuhan mikroorganisme air laut dilakukan di laboratorium mikrobiologi. sampel air laut yang telah diambil dari lapangan dimasukkan dalam inkubator untuk menjaga suhu botol tetap pada temperatur yang sama dengan air laut $\left(27^{\circ} \mathrm{C}\right)$. Sampel pengontrol (pre-test/baseline) dan sesudah perlakuan (post test) ditumbuhkan dalam media NA dengan teknik Total Plate Count di laboratorium untuk kemudian penghitungan jumlah bakteri dengan menggunakan colony counter setelah diinkubasi selama 24 jam. Hal ini dilakukan untuk 
mengetahui apakah ada perbedaan rata-rata jumlah bakteri sebelum dan sesudah perlakuan pada kelompok yang dibacakan ayat Al-Quran serta dibandingkan dengan kelompok kontrol.

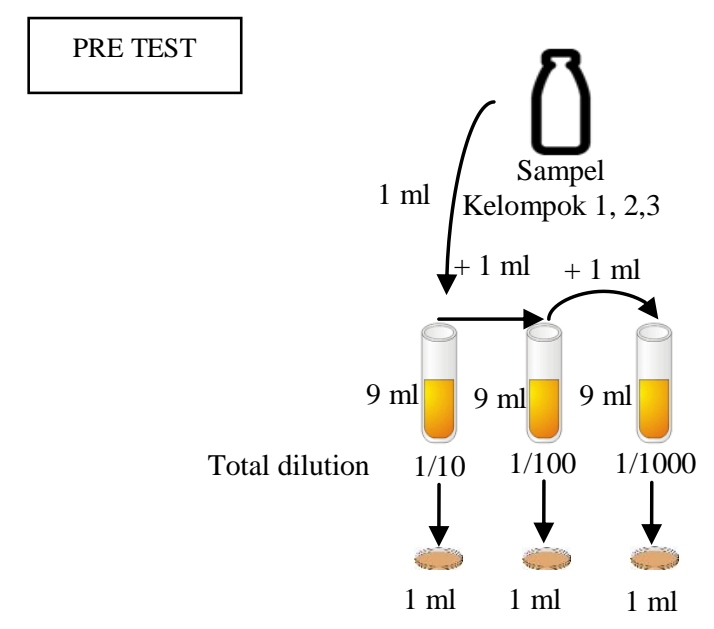

POST TEST

SAMPEL 1

Didengungkan Murottal Al-Fatihah

Selama 3 hari 3 malam

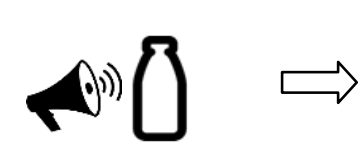

SAMPEL 2

Didengungkan Murottal An-Nahl: 14

Selama 3 hari 3 malam

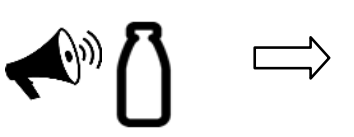

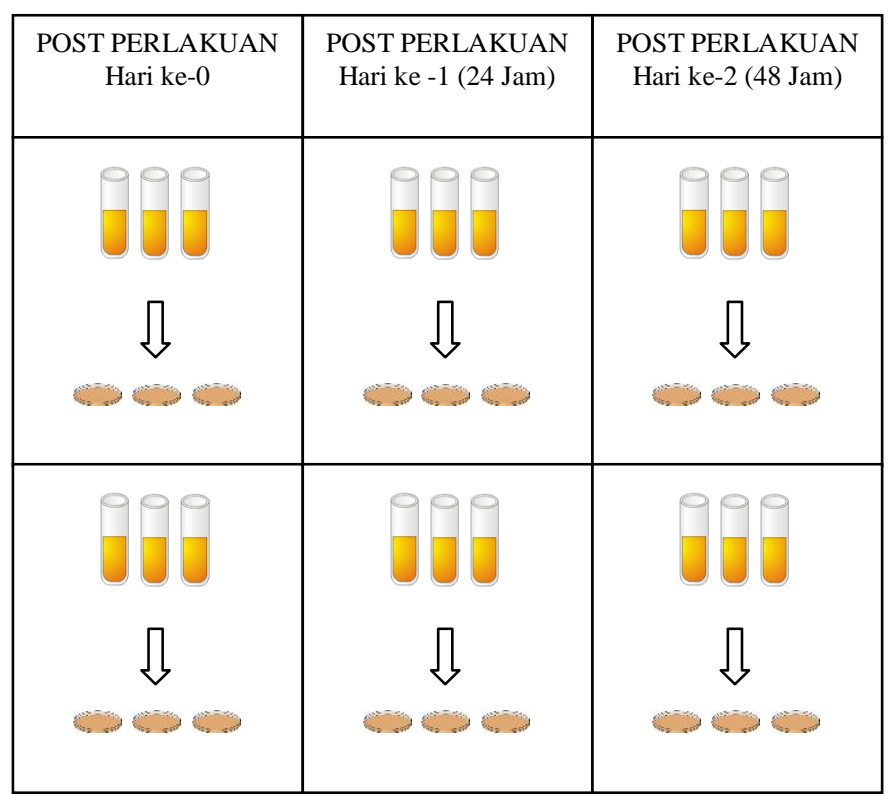

SAMPEL 3

Tanpa Perlakuan (control)

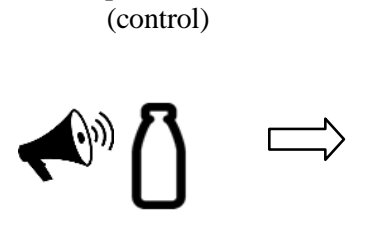

\begin{tabular}{|c|c|c|}
\hline $\begin{array}{c}\text { Post Tanpa } \\
\text { Perlakuan } \\
\text { Hari ke-0 }\end{array}$ & $\begin{array}{c}\text { Post Tanpa } \\
\text { Perlakuan } \\
\text { Hari ke-1 (24 Jam) }\end{array}$ & $\begin{array}{c}\text { Post Tanpa } \\
\text { Perlakuan } \\
\text { Hari ke-2 (48 Jam) }\end{array}$ \\
\hline 090 & 090 & 090 \\
$\square$ & 0 & 0 \\
\hline
\end{tabular}

Catatan: Pengujian post perlakuan sama dengan metode pretest 


\section{HASIL PENGAMATAN LABORATORIUM}

Cawan yang dipilih untuk penghitungan koloni adalah yang mengandung antara 30-300 koloni. Dalam penelitian ini, berdasarkan hasil pengamatan di laboratorium mikrobiologi, banyaknya koloni setelah diencerkan adalah kurang dari 30 koloni, sehingga tidak dapat dihitung dengan menggunakan metode hitungan cawan atau Total Plate Count (TPC). Total jumlah bakteri pada sampel air laut yang diteliti pada penelitian ini diberikan pada Tabel 1. Data pada tabel tersebut adalah data sebelum dilakukan pengenceran pada sampel.

Tabel 1. Nilai Total Plate Count (TPC) Bakteri Sampel Air Laut

\begin{tabular}{|c|c|c|c|c|}
\hline \multirow[b]{2}{*}{ Perlakuan } & \multirow[b]{2}{*}{ Ulangan } & \multicolumn{3}{|c|}{ Nilai TPC (CFU/ml) } \\
\hline & & Hari ke-0 & $\begin{array}{c}\text { Hari ke-1 } \\
(24 \text { jam })\end{array}$ & $\begin{array}{c}\text { Hari ke-2 } \\
(48 \text { jam })\end{array}$ \\
\hline \multirow{3}{*}{$\begin{array}{c}\text { Kontrol (Tanpa } \\
\text { Perlakuan) }\end{array}$} & 1 & 78 & 56 & 57 \\
\hline & 2 & 88 & 125 & 32 \\
\hline & 3 & 72 & 150 & 53 \\
\hline & Rata-Rata: & 79.3 & 110.3 & 47.3 \\
\hline \multirow{3}{*}{ Al Fathihah } & 1 & 58 & 173 & 46 \\
\hline & 2 & 86 & 101 & 32 \\
\hline & 3 & 61 & 154 & 49 \\
\hline & Rata-Rata: & 68.3 & 142.6 & 42.3 \\
\hline \multirow{3}{*}{ An-Nahl } & 1 & 22 & 58 & 49 \\
\hline & 2 & 50 & 86 & 53 \\
\hline & 3 & 28 & 61 & 34 \\
\hline & Rata-Rata: & 33.3 & 68.3 & 45.3 \\
\hline
\end{tabular}

Sumber: data pengamatan laboratorium (2016)

Hasil pengamatan menunjukkan jumlah bakteri pada petri disk yang diisi dengan media NA (Nutrien Agar) menunjukkan adanya pertumbuhan, baik pada kelompok kontrol maupun pada kelompok dengan perlakuan. Pertumbuhan bakteri tersebut berkisar antara 22 colony forming unit (CFU)/ml sampel hingga $173 \mathrm{CFU} / \mathrm{ml}$ sampel, seperti ditunjukkan pada Tabel 1. Rata-rata jumlah bakteri tertinggi pada hari ke-1, setelah masa inkubasi selama 24 jam, ditunjukkan oleh perlakuan bacaan surat Al-Fatihah, yaitu 142,6 CFU/ml sampel. Sementara pada hari ke-2, setelah 48 jam inkubasi, rata-rata jumlah bakteri tertinggi adalah pada kelompok kontrol, yaitu 47,3 CFU/ml, diikuti dengan kelompok perlakuan An-Nahl dengan rata-rata jumlah bakteri 45,3 $\mathrm{CFU} / \mathrm{ml}$ (Tabel 1).

Dari hasil pengamatan yang telah dilakukan, terlihat pola pertumbuhan jumlah koloni mikroba yang sama pada kedua kelompok dengan perlakuan, yaitu penambahan jumlah koloni terjadi pada hari ke-1, setelah 24 jam inkubasi (Tabel 1). Hal ini dikarenakan pertambahan waktu inkubasi dapat meningkatkan jumlah sel bakteri. Selain itu, penambahan jumlah koloni juga disebabkan tersedianya nutrisi yang cukup dalam media pertumbuhan. Pelczar dan Chan (1986) mengatakan bahwa dengan tersedianya nutrisi yang cukup dan kondisi lingkungan yang memadai, maka mikroba akan tumbuh dan berkembang. Pertumbuhan sel mikroba merupakan hasil pembelahan, sehingga menambah jumlah individu.

Hal lain terlihat pada pengamatan hari ke-2, setelah 48 jam inkubasi, dimana terjadi penurunan jumlah koloni mikroba, baik pada kelompok kontrol maupun pada kelompok dengan perlakuan. Keadaan ini dikarenakan ketersedian nutrisi yang telah habis serta kondisi lingkungan yang tidak menunjang. Selain itu, banyak metabolit sekunder berupa toksin yang dihasilkan oleh bakteri sehingga populasi bakteri akan menurun jumlahnya. Pada akhirnya jumlah sel bakteri yang mati lebih banyak daripada sel bakteri yang hidup.

\section{Analisa Data}

Dalam penelitian ini, untuk menguji sebaran data awal dilakukan uji normalitas dengan menggunakan analisis one-sample Kolmogorov-Smirnov test. Uji normalitas dilakukan dengan menggunakan software SPSS Statistic 17. Dari hasil analisis one-sample Kolmogorov-Smirnov test didapat nilai signifikansi sebesar 0.121 ( $>0.05)$ 
yang berarti data nilai TPC adalah berdistribusi normal. Nilai rata-rata keseluruhan data TPC adalah 70.81 $\mathrm{cfu} / \mathrm{ml}$

Langkah berikutnya adalah melakukan uji homogenitas, dimana asumsi homogenitas terpenuhi jika nilai signifikansi pada Levene's Test di atas 0,05 . Uji homogenitas untuk variabel uji dalam penelitian ini menunjukkan nilai signifikansi dibawah 0.05 . Hasil tersebut menunjukkan bahwa asumsi homogenitas tidak terpenuhi dan pengujian hipotesis dilanjutkan dengan menggunakan analisis non-parametrik uji Friedman. Dalam penelitian ini, data hasil pengamatan jumlah koloni bakteri akan diuji dengan dengan menggunakan dua variabel yaitu perlakuan dan hari. Pengujian hipotesis uji statistik dengan menggunakan uji Friedman terlihat bahwa besaran nilai Chi Square $=30.545$ dan asymp sig sebesar 0.000. Hasil uji signifikansi Chi Square menunjukkan bahwa sig < 0.05 sehingga dapat disimpulkan bahwa ketiga perlakuan (tanpa perlakuan (control), dibacakan surat an-Nahl dan al-Fatihah) memberikan reaksi yang berbeda dengan jumlah nilai TPC atau pertambahan koloni bakteri air laut.

\section{KESIMPULAN}

Data pengamatan pertumbuhan mikroorganisme/bakteri dari sampel air laut di laboratorium yang diuji secara statistik dengan menggunakan uji Friedman, dengan menggunakan dua variable, yaitu perlakuan (dibacakan surat Al-Fatihah, An-Nahl, dan tanpa perlakuan) dan hari pengamatan. Hasil uji statistik menunjukkan bahwa nilai signifikansi $<0.05$ sehingga dapat disimpulkan bahwa ketiga perlakuan (dibacakan surat al-Fatihah, anNahl, dan tanpa perlakuan (kontrol) memberikan reaksi yang berbeda dengan pertumbuhan koloni bakteri air laut/jumlah nilai TPC.

\section{DAFTAR PUSTAKA}

Afriati. 2003. Peranan Mikroorganisme Dalam Pengelolaan Limbah. Semarang.

Afriyanto E. 2005. Pakan Ikan dan Perkembangannya. Jakarta: Kanisius.

Baumann, P. \& Baumann, L. 1981. The marine gram negatif Eubacteria: Genera

Bertrand,J.C;Bazin,H.\& Azonlay, E. 1976. Isoloment et etude d'une bacterie marine se development sur hydrocarbunes. H. etude de la lyse et de la viabilite. Ann. Microbiol.(Ins. Pasteur) 127B;393-409.

Daniel, W. W. 1989. Statistik Non-parametrik Terapan. Jakarta: Gramedia.

Dean dan Dalrymple. 2002. Coastal Processes with Engineering Aplication. UK: Cambridge University Press.

Dewi, Ida Ayu Komang Sintia, Luh Putu Sendratari, I Wayan Mudana. 2014. Pemertahanan Tradisi Budaya Petik Laut oleh Nelayan Hindu dan Islam di Desa Pekutatan, Jembrana-Bali. Artikel. Jurusan Pendidikan Sejarah, Fakultas Ilmu Sosial, Universitas Pendidikan Ganesha, Singaraja.

Doneker, Robert L., dan Gerhard H. Jirka, 2007. CORMIX User Manual: A Hydrodynamic Mixing Zone Model and Decision Support System for Pollutant Discharges into Surface Waters. Washington DC: USEPA.

Dwidjoseputro, D. 2005. Dasar-Dasar Mikrobiologi. Djambatan : Jakarta

Farisa, Tomi Latu, 2010. Ritual Petik Laut dalam Arus Perubahan Sosial di Desa Kedungrejo, Muncar, Banyuwangi, Jawa Timur. Skripsi. Program Studi Sosiologi Agama, Fakultas Ushuludin, Universitas Islam Negeri Sunan Kalijaga Yogyakarta.

Harmita. 2006. Buku Ajar Analisis Hayat. Jakarta: Kedokteran EGC. Ed. ke-3.

Hojjati, A., Rahimi, A., Farehani, M.D., Sobhi-Gharamaleki, N., Alian, B. 2014. Effectiveness of Quran Tune on memory in children. Procedia - Social and Behavioral Sciences 114 (2014) 283 - 286.

Hutabarat, Sahala, dan Evans, Stewart M. 1985. Pengantar Oseanografi. Jakarta: UI-Press.

Geertz C. 2014. Agama Jawa Abangan, Santri, Priyayi Dalam Kebudayaan Jawa. Komunitas Bambu. Cetakan ke-2.

Kamal, N.F., Mahmood, N.H., Zakaria, N.A. 2013. Modeling brain activities during reading working memory task: Comparison between reciting Quran and reading book. Procedia - Social and Behavioral Sciences 97 (2013) $83-89$.

Mukhtasor. 2007. Pencemaran Pesisir dan Laut. Jakarta: Pradnya Paramita. 
Nelson, Stephen, A. tanpa tahun. Tulane University Lecture Notes. Dikutip dari http://earthsci.org/education/teacher/basicgeol/coastal/coastal.html (diakses pada 10 September 2013 pukul 11.04)

Nontji, Anugerah. 1987. Laut Nusantara. Jakarta: Djambatan.

Pinet, Paul R. 1999. Invitation to Oceanography 2nd edition. USA: Jones \& Bartlett Publishers.

Putra. H.S. Ahimsa, 2012. “The Living Al-Quran: Beberapa Perspektif Antropologi” Jurnal Walisongo, Vol.20, No.1, Mei 2012.

Rohim, Abdul Gafurur. 2009. Tradisi Petik Laut dan Pengaruhnya terhadap Keberagaman Masyarakat Nelayan Desa Pugerkulon Kecamatan Puger Kabupaten Jember. Skripsi. Program Studi Sosiologi Agama, Fakultas Ushuluddin, Universitas Islam Negeri Sunan Kalijaga, Yogyakarta.

Silvia, Shinta. 2001. Biodegradasi Hidrokarbon Minyak Bumi. Universitas Andalas: Padang Triatmojo, Bambang. 1999. Teknik Pantai. Yogyakarta: Beta Offset.

Yin, Robert K. 2003. "Introduction”, in Case Study Research. London: SAGE Publications, pp 1-18. 